\title{
Improvement in Morphology and Organic Substances of Vigna radiata Growing Under Conocarpus erectus and Moringa oleifera Amended Soil
}

\author{
Shabana Askari1 ${ }^{1, *}$, Ayesha Siddiqui ${ }^{2}$, Sania Razzaque ${ }^{1}$ \\ 1Department of Botany, Jinnah University for Women, Karachi 74600, Pakistan \\ 2Department of Biotechnology, Jinnah University for Women, Karachi 74600, Pakistan
}

\section{ABSTRACT}

Background: Conocarpus erectus is an exotic plant and perpetuate vigorously in saline and calcareous soil of Karachi, whereas Moringa oleifera also easily grows in deserted soil of province of Sind. Both the plant species do not require much water to grow well. Moreover, they contain lots of macro and micronutrients in them which is easily and abundantly available.

Objectives: Current research was conducted to analyze the potentials of both the plant species to improve various growth parameters of economically important Vigna radiata.

Methodology: Experiment was conducted in randomized block fashion. Sterilized seeds of Vigna radiata were sown under different treatments (control, T1, T2, T3). The plants were harvested after 25 days of sowing and various physical and biochemical parameters like shoot length, root length, leaf area, leaf number, biomass, relative water contents, chlorophyll contents, carotenoid contents and carbohydrate contents were determined.

Results: Both the species were found efficient, but Conocarpus erectus shows significant results in enhancing all the morphological and biochemical parameters.

Conclusion: It was concluded from the present study that Conocarpus erectus can promote and enhance the growth of Vigna radiata.

$\begin{array}{lll}\text { Keywords } & \text { *Address of Correspondence } & \text { Article info. } \\ \begin{array}{l}\text { Bio-waste, Conocarpus erectus, Moringa } \\ \text { oleifera, Vigna radiata, Carbohydrate, }\end{array} & \text { shabana.askari@yahoo.com } & \text { Received: August 9, 2019 } \\ \text { Phoccepted: December 31, 2019 } & & \text { Accol }\end{array}$

Photosynthetic pigments.

Cite this article: Askari S, Siddiqui A, Razzaque S. Improvement in Morphology and Organic

Substances of Vigna radiata Growing Under Conocarpus erectus and Moringa oleifera

Funding Source: Nil

Amended Soil. RADS J Biol Res Appl Sci. 2019; 10(2): 87-93.

Conflict of Interest: Nil

This is an Open Access article distributed under the terms of the Creative Commons Attribution License (http://creativecommons.org/licenses/by/4.0), which permits unrestricted use, distribution, and reproduction in any medium, provided the original work is properly cited.

\section{INTRODUCTION}

Increasing salinity and anthropogenic activities have resulted in land degradation which is expected to have overwhelming global effects ${ }^{1}$. Saline soils have adverse effects on plant growth and cause plant death due to ion toxicity, water stress, ion imbalance, or a combination of all these factors ${ }^{2}$. Generally, excessive amounts of inorganic fertilizers are applied to plants in order to achieve a higher yield and economic return. But, such practices are responsible to increase soil acidity and leads to inhibited growth ${ }^{3,4}$. Organic manures are cost effective, eco-friendly and renewable source of plant nutrients to supplement chemical fertilizers, and are commonly known to be used in sustainable agricultural system in India ${ }^{5}$. Biofertilizers enhance plant growth and improve yield, thus, protecting crops from pathogenic fungi. Moreover, use of several bioinoculants has been suggested by many workers for better crop productivity and biological control of diseases ${ }^{6}$. 
Buttonwood (Conocarpus erectus L.), an evergreen tree of the family Combretaceae, has been found to tolerate extreme desert heat (where summer temperatures may reach $47^{\circ} \mathrm{C}$ ) and could grow in low fertile soils ${ }^{7}$. Moringa oleifera also known as drum stick in India, belongs to family Moringaceae, is a well-documented world renowned plant herb for its extraordinary nutritional and medicinal properties ${ }^{8}$. The plant can be best grown in dry sandy or loamy alkaline soili ${ }^{9}$ Vigna radiata L. Wilczek, commonly known as green gram, is one of the important legumes with rich protein content, vitamins and minerals ${ }^{10}$. Present study was based on the question that "Whether Conocarpus erectus and Moringa oleifera improves growth parameters of Vigna radiata".

\section{MATERIALS AND METHODS}

\section{Preparation of Bio-Waste}

Conocarpus erectus and Moringa oleifera leaves were collected from roadsides of Karachi, washed thoroughly, shade dried, ground and kept in air tight bottles for experimental purpose to be used in dosage of $5 \mathrm{~g} / \mathrm{kg}$ soil.

\section{Preparation of Pots}

Four sets of earthen pots in triplicate, containing $1 \mathrm{~kg}$ garden soil were prepared.

- $\quad 1^{\text {st }}$ set named control was not provided with any kind of fertilizer.

- $\quad 2^{\text {nd }}$ set was provided with $5 \mathrm{~g} / \mathrm{kg}$ Conocarpus erectus.

- $\quad 3^{\text {rd }}$ set was provided with $5 \mathrm{~g} / \mathrm{kg}$ Moringa oleifera.

- $4^{\text {th }}$ set was provided with $5 \mathrm{~g} / \mathrm{kg}$ compost (Conocarpus erectus + Moringa oleifera) w/w.

\section{Sterilization and Sowing of Seeds}

Healthy seeds of Vigna radiata were surface sterilized with $1 \%$ bleach followed by frequent washing with distilled water then sown carefully ( 6 seeds/pot). After 25 days plants were harvested and various morphological parameters like root length, shoot length, leaf area, leaf number, biomass and relative water contents were determined. Likewise, some biochemical tests such as chlorophyll contents was determined as described by Helmkapm ${ }^{11}$ and Bioteau ${ }^{12}$ while carotenoid as well as carbohydrate contents were determined according to the procedure described by $\operatorname{Rahman}^{13}$ and Rawa ${ }^{14}$ respectively.

\section{RESULTS AND DISCUSSION}

Current research was focused to evaluate the potentials of abundantly available Conocarpus erectus and Moringa oleifera in enhancing the growth of Vigna radiata. Following parameters were examined;

\section{Shoot Length}

Data presented in Table 1, revealed that shoot length of Vigna radiata growing under three different treatments of agrowaste powder exhibited remarkable differences. The Shoot length of Vigna radiata increased appreciably in Conocarpus erectus amended soil upto $23.84 \pm 0.86 \mathrm{~cm}(\%$ increase 20.64), in Conocarpus + Moringa it was $29 \pm 0.82 \mathrm{~cm}$ (\% increase 46.76), whereas it was $19.76 \pm 0.36 \mathrm{~cm}$ in control. However, application of Moringa oleifera leaf powder did not show any outstanding increment in shoot length of Vigna radiate, it was almost similar to control i.e., $19.54 \pm 1.63 \mathrm{~cm}$ (\% increase -1.11$)$. The data showed that Conocarpus erectus was more effective than Moringa oleifera. Significant increase in shoot length of Vigna radiata by Conocarpus erectus may be attributed to the presence of various antioxidants, macro and micro nutrients, saponins and alkaloids. Antioxidants protect plant from free radicals and oxidation reactions ${ }^{1,4}$. Saponins regulate cellulose synthesis in different plant species ${ }^{2,15}$, and stimulate cortical cell division and elongation 6,16 . The extract of Conocarpus erectus from different parts (leaves, stems, fruits, and flowers) showed high antioxidant, hepatoprotective and anticancer activity due to the presence of phenolic compounds ${ }^{17}$. Various macro and micro nutrients of Moringa and metabolites present in the Conocarpus may be effective in the increase in shoot length of Vigna radiata under the provided compost.

\section{Root Length}

Data obtained from current research showed that root length of Vigna radiata decreased in all applied treatments as compared to control. The root length of Vigna radiata was found to be $14.24 \pm 0.55 \mathrm{~cm}$ (\% increase $-7.66)$ in Conocarpus erectus, $11.44 \pm 1.74 \mathrm{~cm}(\%$ increase -25.81 ) in Moringa oleifera and $9.8 \pm 0.88 \mathrm{~cm}(\%$ increase 36.45 ) by the application of Compost (Conocarpus erectus + Moringa oleifera), whereas, it was 
$15.42 \pm 1.38 \mathrm{~cm}$ in control. Elongated and deep roots are xerophytic characters.

Vigna radiata grown under Conocarpus amended soil exhibited a decrease in root length. This is a normal healthy character and is proved by the data presented in Table 1, 2 \& 3 where all the analyzed parameters like shoot length, RWC, biomass, total chlorophyll and carbohydrates are enhanced. This may be due to the presence of antioxidant as it protects plants from free radicals and oxidation reactions ${ }^{1,4}$. In addition, saponins also stimulate the growth of roots ${ }^{18,19}$ as well as regulate cellulose production ${ }^{2,15}$ and stimulate cortical cell division and elongation 6,16 .

\section{Leaf Area}

Current study revealed outstanding performance of Conocarpus erectus in enhancing the leaf area of Vigna radiata increased upto $13.134 \pm 1.05 \mathrm{~cm}^{2}(\%$ increase 49.04) in Conocarpus erectus amended soil, $8.274 \pm 0.81 \mathrm{~cm}^{2}$ (\% increase -6.1 ) in Moringa added soil, $4.55 \pm 0.39 \mathrm{~cm}^{2} \quad(\%$ increase -48.35$)$ in Compost (Conocarpus + Moringa) supplied soil, whereas it was $8.808 \pm 0.30 \mathrm{~cm}^{2}$ in control (Table 1). Leaf area is limiting factor of biomass production and it varies with nutrient supply ${ }^{20}$. Leaf area is an important variable for most ecophysiological studies in terrestrial ecosystems concerning light interception, evapotranspiration, photosynthetic efficiency, fertilizers, and irrigation response and plant growth. Leaf area estimate is valuable in studies of plant nutrition, plant competition, plant-soilwater relations, plant protection measures, respiration, light reflectance, and heat transfer in plants ${ }^{21}$. Increment in leaf area of Vigna radiata growing under Conocarpus erectus amended soil proved the data of total chlorophyll and carbohydrate contents presented in Table 3 . Expended leaf lamina contains more chlorophyll which performs more photosynthesis and hence produced enhanced carbohydrate contents and this also supports the data of biomass given in Table 2 . This may be related with the presence of various antioxidants and saponins in Conocarpus erectus which enhanced cell division and expansion. Increased leaf area also supports the results of shoot length, number of leaf, biomass and relative water contents. Leaf area of Vigna radiate growing under Moringa oleifera amended soil remain unchanged, this may be due to some experimental error, because some authors like ${ }^{15,22}$ reported positive effects of Moringa oleifera on plant growth.

\section{Leaf Number}

Numbers of leaves of Vigna radiata were enhanced considerably by the application of Conocarpus erectus upto $6.4 \pm 0.68$ (\% increase 23.07), it increased15,22 to some extent under Moringa oleifera amended soil upto $5.4 \pm 0.40$ (\% increase 3.85), whereas a decrease in number of leaves were noticed under Compost (Conocarpus + Moringa) amended soil upto $3.666 \pm 0.88$ (\% increase -29.42). Number of leaves were $5.2 \pm 0.20$ in control (Table 1). Number of leaves of Vigna radiata grown under Conocarpus amended soil increased upto $23 \%$ which is fairly good as compared to the plants grown in Moringa, Compost and control. Saponins are secondary metabolites and have important job in growth and development of plants that could be the reason of increase in the number of leaves.

\section{Fresh Weight}

Fresh weight of Vigna radiata growing under Conocarpus erectus amended soil was found to be $0.58 \pm 0.07 \mathrm{~g}$ (\% increase 65.71), whereas it was $0.44 \pm 0.02 \mathrm{~g}$ (\% increase 25.71) in Moringa oleifera and under compost (Conocarpus + Moringa) powder it was $0.31 \pm 0.02 \mathrm{~g}$ (\% increase -11.42). Fresh weight of control plants was recorded as $0.35 \pm 0.01 \mathrm{~g}$ (Table 2). Fresh weight of Vigna radiata was higher in Conocarpus erectus amended soil as compared to Moringa oleifera, compost and control plants, this may attribute to the presence of various nutrients present in Conocarpus erectus which enhanced overall growth of plant. This data may be correlated with all other analyzed morphological and biochemical parameters which indicates an increased metabolic activity in Vigna radiate due to various macro and micronutrients found in Conocarpus erectus (Table 1). 
Table 1. Effect of Conocarpus erectus, Moringa oleifera and Compost (Conocarpus erectus + Moringa oleifera) on Shoot Length, Root Length, Number of Leaves and Leaf Area of Vigna radiata.

\begin{tabular}{cccccccccc}
\hline $\begin{array}{c}\text { S. } \\
\text { No. }\end{array}$ & Treatment & $\begin{array}{c}\text { Shoot length } \\
(\mathbf{c m})\end{array}$ & $\begin{array}{c}\% \\
\text { Increase }\end{array}$ & $\begin{array}{c}\text { Root length } \\
(\mathbf{c m})\end{array}$ & $\begin{array}{c}\% \\
\text { Increase }\end{array}$ & $\begin{array}{c}\text { Leaf area } \\
\left(\mathbf{c m}^{2}\right)\end{array}$ & $\begin{array}{c}\% \\
\text { Increase }\end{array}$ & $\begin{array}{c}\text { No. of } \\
\text { leaves }\end{array}$ & $\begin{array}{c}\% \\
\text { Increase }\end{array}$ \\
\hline 1 & Control & $19.76 \pm 0.36$ & - & $15.42 \pm 1.38$ & - & $8.81 \pm 0.30$ & - & $5.2 \pm 0.20$ & - \\
\hline 2 & $\begin{array}{c}\text { Conocarpus } \\
\text { erectus }\end{array}$ & $23.84^{*} \pm 0.86$ & 20.64 & $14.24 \pm 0.55$ & -7.66 & $13.13^{*} \pm 1.06$ & 49.04 & $6.4 \pm 0.68$ & 23.07 \\
\hline 3 & $\begin{array}{c}\text { Moringa } \\
\text { oleifera }\end{array}$ & $19.54 \pm 1.63$ & -1.11 & $11.44^{*} \pm 1.74$ & -25.81 & $8.27 \pm 0.81$ & -6.1 & $5.4 \pm 0.40$ & 3.85 \\
\hline 4 & Compost & $29 * \pm 0.82$ & 46.76 & $9.8 * \pm 0.88$ & -36.45 & $4.55^{*} \pm 0.39$ & -48.35 & $3.67 * \pm 0.88$ & -29.42 \\
\hline
\end{tabular}

Result express as Mean \pm SEM of triplicate. Marked effects are significant at $p<0.05000$ (*indicated significant values of treated plants over control ones. $n=3$.

Table 2. Effect of Conocarpus erectus, Moringa oleifera and Compost on Fresh Weight, Dry Weight, Biomass and Relative Water Content (R.W.C) of Vigna radiata Plant.

\begin{tabular}{cccccccccc}
\hline $\begin{array}{c}\text { S. } \\
\text { No. }\end{array}$ & Treatment & $\begin{array}{c}\text { Fresh wt. } \\
(\mathbf{g})\end{array}$ & $\begin{array}{c}\% \\
\text { Increase }\end{array}$ & Dry wt. $(\mathbf{g})$ & $\begin{array}{c}\% \\
\text { Increase }\end{array}$ & $\begin{array}{c}\text { Biomass } \\
(\mathbf{g})\end{array}$ & $\begin{array}{c}\% \\
\text { Increase }\end{array}$ & R. W. C (\%) & $\begin{array}{c}\% \\
\text { Increase }\end{array}$ \\
\hline 1 & Control & $0.35 \pm 0.01$ & - & $0.06 \pm 0.03$ & - & $0.29 \pm 0.01$ & - & $33.23 \pm 3.71$ & - \\
\hline 2 & $\begin{array}{c}\text { Conocarpus } \\
\text { erectus }\end{array}$ & $0.58^{*} \pm 0.07$ & 65.71 & $0.10 * \pm 0.06$ & 66.66 & $0.48 * \pm 0.04$ & 65.51 & $79.66 * \pm 2.72$ & 139.72 \\
\hline 3 & $\begin{array}{c}\text { Moringa } \\
\text { oleifera }\end{array}$ & $0.44 \pm 0.02$ & 25.71 & $0.08 * \pm 0.05$ & 33.33 & $0.36 \pm 0.02$ & 24.13 & $74.06 * \pm 3.73$ & 122.87 \\
\hline 4 & Compost & $0.31 \pm 0.02$ & -11.42 & $0.06 \pm 0.03$ & 0 & $0.25 \pm 0.01$ & -13.79 & $61.51 * \pm 8.95$ & 85.10 \\
\hline
\end{tabular}

Result express as Mean \pm SEM of triplicate. Marked effects are significant at $p<0.05000$ ( ${ }^{*}$ indicated significant values of Treated plants over control ones. $n=3$.

\section{Dry Weight}

Present data revealed an increment in dry weight of Vigna radiata upto $0.10 \pm 0.06 \mathrm{~g}(\%$ increase 66.66$)$ growing in the application of Conocarpus erectus, $0.08 \pm 0.05 \mathrm{~g}(\%$ increase 33.33) in Moringa oleifera, and 0.06 $\pm 0.03 \mathrm{~g}(\%$ increase 0 ) in Compost (Conocarpus + Moringa) whereas it was found to be $0.06 \pm 0.03 \mathrm{~g}$ in control (Table 2). Dry weight of Vigna radiata growing under Conocarpus erectus amended soil was found to be exceptionally improved (Table 2). Increased dry weight may be correlated with the results of root length, shoot length, biomass, total chlorophyll and carbohydrate contents (Table 1, 2, 3) because increased metabolic activities and photosynthesis means enhanced dry weight.

\section{Biomass}

Biomass is the actual weight or organic matter of the plant body obtained after the removal of water. Current research data showed that Vigna radiata grown under the application of Conocarpus erectus leaf powder had appreciably increased the biomass as compared to control which was found to be $0.48 \pm 0.04 \mathrm{~g}$ (\% increase 65.51). It was $0.36 \pm 0.02 \mathrm{~g}$ (\% increase 24.13 ) in Moringa oleifera amended soil, and $0.25 \pm 0.01 \mathrm{~g}(\%$ increase 13.79) in compost (Conocarpus + Moringa), whereas it was $0.29 \pm 0.01 \mathrm{~g}$ in control (Table 2). Data indicated a noteworthy increment in biomass of Vigna radiata supplied with Conocarpus erectus leaf powder (65.51\%), this may attribute to the presence of various macro and micro nutrient and lot of organic substances. Results of biomass are being supported by Table 1 and 2 . It may be concluded that if roots are healthy, they will absorb and transport water and minerals in maximum to leaves where adequate amount of elaborated food stuff are formed as a result of photosynthesis. So the whole plant acquired maximum growth by increasing its biomass. Biomass contains stored energy from the sun. Conocarpus erectus found to be as good as an efficient and eco-friendly fertilizer. 


\section{Relative Water Content}

Relative water content (RWC) is the most suitable measure of plant water status in terms of the physiological significance of cellular water deficit. Current research showed that the Conocarpus erectus leaf powder and Moringa oleifera leaf powder had considerable effect on relative water content of Vigna radiata. The data was found to be $79.66 \pm 2.72 \%$ (\% increase 139.72) in Conocarpus, $74.06 \pm 3.73 \%$ (\% increase 122.87) in Moringa, $61.51 \pm 8.95 \%$ (\% increase 85.10 ) in compost (Conocarpus + Moringa), whereas it was $33.23 \pm 3.713 \%$ in control. The treatment with Conocarpus and Moringa leaf powder had beneficial effects on relative water content of Vigna radiata. Relative water content (RWC) of Vigna radiata growing under the application of Conocarpus erectus amended soil is higher than other treatments in current research may be due to increased leaf area, no of leaf and healthy root system which absorb efficient water and mineral (Table 1).

\section{PHOTOSYNTHETIC PIGMENTS}

\section{Chlorophyll-a}

Chlorophyll a functions as a primary electron donor during the election transport chain in photosynthesis. This is the molecule which makes photosynthesis possible, by passing its energized electrons on to molecules which will manufacture sugars. Current data revealed that the chlorophyll of a Vigna radiata was found to be $2.242 \pm 0.27$ (\% increase 124.2) in Conocarpus erectus, 0.638 \pm 0.04 (\% increase -53.96) in Moringa oleifera, 1.294 \pm 0.19 (\% increase -6.71) in compost (Moringa + Conocarpus), whereas it was $1.387 \pm 0.72 \mathrm{mg} / \mathrm{g}$ fresh wt. in control (Table 3). The role of bio-waste is well known sole application and incorporated with chemical fertilizer recorded highest Chlorophyll (a) and (b) contents as compared to control treatment ${ }^{1}$. Data mentioned in Table 1 and 2 especially data of leaf area and leaf number highly supported the result of Chl-a. Application of Conocarpus erectus leaf powder greatly enhanced Chl-a contents in Vigna radiata which may be due to the charqacteristic features of the antioxidants, alkaloids and saponins. Antioxidants interact with free radicals and help protect cells from damage hence enhance growth. Alkaloids protect plants from herbivore; some of them may function as growth regulators and may substitute minerals in plants ${ }^{23}$.
Application of saponins to plants enhances various physiological processes ${ }^{24}$ for instance swift germination due to quick imbibition of water by seeds, twice the growth rate of some embryos ${ }^{12}$, stimulate growth and chlorophyll biosynthesis ${ }^{25}$, regulate cellulose synthesis in different plant species ${ }^{18,26}$, stimulate cortical cell division and elongation leading to enhanced growth of roots ${ }^{19}$.

\section{Chlorophyll-b}

Chlorophyll $b$ is more soluble than chlorophyll a in polar solvents because of its carbonyl group. In land plants, the light-harvesting antennae around photosystem II contain the majority of chlorophyll $b$. The data of chlorophyll b was found to be $1.4367 \pm 0.05$ (\% increase 30.07) in Vigna radiata by the application of Conocarpus erectus leaf powder, $0.9776 \pm 0.11$ (\% increase -11.50) in Moringa oleifera, $0.645 \pm 0.16$ (\% increase -41.57) in compost (Moringa + Conocarpus). Whereas it was1.1046 \pm 0.37 $\mathrm{mg} / \mathrm{g}$ fresh wt., in control. Current data revealed that chlorophyll b content of Vigna radiata increased significantly with the application of Conocarpus erectus (Table 3) this may attribute to the presence of saponins which stimulate growth and chlorophyll biosynthesis in Vigna radiata ${ }^{1,25}$. Moreover Conocarpus erectus contain antioxidants and alkaloids which not only protect cells from reactive oxygen species but also provide substitute minerals for growth, this might be the reason of an increment in chlorophyll b of Vigna radiata.

\section{Total Chlorophyll Contents}

The result showed that the total chlorophyll contents in Vigna radiata were found to be $3.677 \pm 0.29$ (\% increase $48.20)$ by the application of Conocarpus erectus leaf powder,1.615 \pm 0.12 (\% increase -34.90$)$ under the treatment of Moringa oleifera leaf powder, and1.938 \pm 0.06 (\% increase -21.88) in compost (Moringa + Conocarpus), whereas it was $2.481 \pm 1.11 \mathrm{mg} / \mathrm{g}$ fresh wt. in control plants. The total Chlorophyll content in Vigna radiata enhanced greatly by the application of Conocarpus erectus (Table 3), this may attribute to the presence of antioxidants, alkaloids, saponins and various other macro and micro nutrients in Conocarpus erectus ${ }^{1}$. Increment in total chlorophyll contents of Vigna radiata by the application of Conocarpus erectus greatly improved the rate of photosynthesis and hence photosynthetic products, thus overall growth of Vigna radiata enhanced. 
Data presented in Table 1, 2 and 3 revealed that Conocarpus erectus among other two treatments i.e., Moringa oleifera and compost (Moringa + Conocarpus) is an efficient biowaste which improved the overall growth of Vigna radiata and can be used as an effective, low cost and ecofriendly biowaste fertilizer.

\section{Carotenoids}

Carotenoids are coloured pigments, they do not directly involve in the process of photosynthesis rather they transmit their absorbed light energy to chlorophyll. They also protect chlorophyll from photodamage. Carotenoids absorb light in the blue-green and violet region and reflect the longer yellow, red, and orange wavelengths. Current study revealed that Vigna radiata grown under the application of Conocarpus erectus leaf powder exhibited significant enhancement as compared to control and other two treatments. Carotenoid content was found to be $0.723 \pm 0.03$ in Conocarpus erectus, $0.319 \pm 0.02$ in Moringa oleifera, $0.429 \pm 0.03$ in compost (Conocarpus erectus + Moringa oleifera) whereas it was $0.486 \pm 0.31$ $\mathrm{mg} / \mathrm{g}$ fresh wt. in control. Application of Conocarpus erectus leaf powder greatly improved the overall growth of Vigna radiata which may be verified by the data presented in Table 1, 2 and $\mathbf{3 .}$

Table 3. Effect of Conocarpus erectus, Moringa oleifera and Compost (Conocarpus erectus + Moringa oleifera) on Chl-a, Chl-b, Total Chl (mg/gm Fresh wt), Carotenoids and Carbohydrate ( $\mu \mathrm{mol} / \mathrm{gm})$ Fresh Weight of Vigna radiata.

\begin{tabular}{|c|c|c|c|c|c|c|c|c|c|c|c|}
\hline $\begin{array}{l}\text { S. } \\
\text { No. }\end{array}$ & Treatment & Chl-a & $\begin{array}{c}\% \\
\text { Increase }\end{array}$ & Chl-b & $\begin{array}{c}\% \\
\text { Increase }\end{array}$ & Total Chl. & $\begin{array}{c}\% \\
\text { Increase }\end{array}$ & Carotenoids & $\begin{array}{c}\% \\
\text { Increase }\end{array}$ & $\mathrm{CHO}$ & $\begin{array}{c}\% \\
\text { Increase }\end{array}$ \\
\hline 1 & Control & $1.386 \pm 0.72$ & - & $1.104 \pm 0.37$ & - & $2.481 \pm 1.11$ & - & $0.486 \pm 0.31$ & - & $42.41 \pm 9.56$ & - \\
\hline 2 & $\begin{array}{l}\text { Conocarpus } \\
\text { erectus }\end{array}$ & $2.242 \pm 0.27$ & 124.2 & $1.436^{*} \pm 0.05$ & 30.07 & $3.677 \pm 0.29$ & 48.20 & $0.723^{*} \pm 0.03$ & 48.76 & $56.86^{*} \pm 6.42$ & 34.07 \\
\hline 3 & $\begin{array}{l}\text { Moringa } \\
\text { oleifera }\end{array}$ & $0.638 * \pm 0.04$ & -53.96 & $0.977^{*} \pm 0.11$ & -11.50 & $1.615 \pm 0.12$ & -34.90 & $0.319 * \pm 0.02$ & -34.36 & $35.92 \pm 2.48$ & -15.30 \\
\hline 4 & Compost & $1.293 \pm 0.19$ & -6.71 & $0.645^{*} \pm 0.16$ & -41.57 & $1.938 \pm 0.06$ & -21.88 & $0.429 \pm 0.03$ & $\begin{array}{l}-11.73 \\
\end{array}$ & $49.99 * \pm 9.47$ & 17.87 \\
\hline
\end{tabular}

Result express as Mean \pm SEM of triplicate. Marked effects are significant at $p<0.05000$ (*indicated significant values of treated plants over control ones. $n=3$.

\section{Carbohydrate Content}

Carbohydrates are photosynthetic products, they not only provide structural component to plants but also deliver energy for growth and development. Current study showed that Vigna radiata grown under Conocarpus erectus leaf powder had significantly enhanced carbohydrate content as compared to control. Data presented in Table 3 revealed that carbohydrate content of Vigna radiate was found to be $56.86 \pm 6.42$ under the application of Conocarpus erectus, $35.92 \pm 2.48$ in Moringa oleifera, and $49.99 \pm 9.47$ in compost (Conocarpus erectus + Moringa oleifera) whereas it was $42.41 \pm 9.56 \mu \mathrm{mol} / \mathrm{g}$ fresh wt. in control plants. The carbohydrate contents of Vigna radiate was found to be highest by the application of Conocarpus erectus leaf powder. This attribute may be due to overall improvement in the number of leaves, leaf area, relative water contents, chlorophyll contents and carotenoids and this is strongly supported by the data presented in Table 1, 2 and $\mathbf{3}$.

\section{CONCLUSION}

It was concluded from the present study that Conocarpus erectus can promote and enhance the growth of Vigna radiata. The overall results showed that Conocarpus erectus significantly increased the morphological as well as biochemical parameters of Vigna radiata. We can conclude this study that vigorous vegetative growth of Conocarpus erectus is easy and free of cost availability. There are a number of wild plants which can be used as bio-waste. The plants used as a bio-fertilizer have no side effects and greatly enhance plant growth and most importantly cost effective and eco-friendly. Data from present study confirmed the high efficiency of Conocarpus erectus leaf powder to enhance the growth of experimental plant 'Vigna radiata'. Pakistan's economy is based on agriculture, but most of our farmers who are poor and illiterate, use synthetic fertilizer to improve their crops yield. After a certain period of time these fertilizers 
increases the toxicity of soil in terms of salinity, change in $\mathrm{pH}$ and accumulation of poisonous compounds. We used Conocarpus erectus (bio-waste) as a fertilizer which has no apparent harmful effect on plants with a marked increase in yield and quality of crop. Hence, Conocarpus erectus may further be investigated on other crops, to enhance crop productivity and soil fertility.

\section{LIST OF ABBREVIATIONS}

$\begin{array}{ll}\text { RWC } & \text { Relative water content } \\ \text { Chl - a } & \text { Chlorophyll }-a \\ \text { Chl - b } & \text { Chlorophyll }-\mathrm{b} \\ \text { SEM } & \text { Standard Error Mean } \\ \text { Wt } & \text { Weight }\end{array}$

\section{REFERENCES}

1. Waller GR, Nowacki EK. The role of alkaloids in plants. In: Alkaloid biology and metabolism in plants. Springer, Boston, MA. 1978.

2. Bor M, Ozdemir F, Turkan I. The effect of salt stress on lipid per oxidation and an Antioxidants in leaves of sugar beet Beta vulgarism L. and wild beet Beta maritime L. Plant Sci. 2003; 164:77-84.

3. Megan ER, Mirwais MQ. Individual and interactive effects of temperature, carbon dioxide and abscisic acid on mung bean (Vigna radiata) plants. J Plant Interaction. 2017; 12(1):295303.

4. Askari S, Khurshid H. Conocarpus mediated improvement in photosynthetic pigments of Cicerarietinum growing under copper stress. RADS J Biol Res Appl Sci. 2018; 9(1):41-9.

5. Wani SP, Lee KK. Biofertilizers for sustaining cereal crop production. In: Kannaiyan, S. (ed.). Biotechnology of biofertilizers, Narosha Publishing House; 2002.

6. Chankee KS, Kumar P, Dubey RC. Carrier based tripartite bacterial consortia promote growth of Lycopersicon esculentum L. J Sci Trans Environ Techno. 2015; 8:173-7.

7. Ansary EM, Al-Humaid Al. Response of Buttonwood (Conocarpus erectus) trees to drought conditions. J Agri Marine Sci. 2007; 12:21-34.

8. Malliga E, Dhanarajan MS, Rajalakshmi A, Jayachitra A, Pardhasaradhi $M$, Narasimharao B. Analysis of phytochemicals, antibacterial and antioxidant activities of Moringa oleifera Lam. leaf extract- an in vitro study. Int J Drug Dev Res. 2014; 6(4):173-80.

9. Mehra M, Jakhar N, Joshi S, Meghwal M. Phytotherapaeutic functionality of Moringa oleifera Lam for health. Int J cell Sci Mol Boil. 2017; 3(3):1-4.

10. Emad MA. Antibacterial properties of leaf extracts of Moringa oleifera Lam. growing in Sudan. JAMPS. 2016; 5(1):1-5.
11. Helmkamp G, Bonner J. Some relationships of sterols to plant growth. Plant Physiol. 1953; 28:428-36.

12. Boiteau $P$, Ratsimamanga AR. Asiaticoside extracted from Centellaasiatica and its therapeutic uses in cicatrization of experimental and refractory wounds (leprosy, cutaneous tuberculosis and lupus) Therapie. 1956; 11:125-49.

13. Rahman A, Ahamed A, Amakawa T, Goto N, Tsurumi S. Chromosaponin I specifically interacts with AUX1 protein in regulating the gravitropic response of Arabidopsis roots. Plant Physiol. 2001; 125:990-1000.

14. Rawa AH. Evaluation antioxidant and antibacterial activities of n-butanol fraction of Conocarpus erectus leaves extract. International J Pharm Med Res. 2016; 4(6):394-400.

15. Abusuwar AO, Abohassan RA. Effect of Moringa olifera leaf extract on growth and productivity of three cereal forages. Journal of Agricultural Science. 2017; 9(7):236-43.

16. Sharma CK, Dubey RC. Plant growth promoting and antagonistic properties of Pseudomonas putidaCRN-09 Against Macrophomina phaseolina (Tassi) Goid. Indian J Sci Res. 2017; 13(2):1-5.

17. Maryam B, Muhammad U, Bashir AC. A review of phytochemical and biological studies on Conocarpus erectus (combretaceae). Pak J Phar Res. 2015; 1(1):1-8.

18. Seiji T, Shunji W. Chromosaponin I stimulates the elongation of cortical cells in lettuce roots. Plant Cell Physiol. 1995; 36(5):925-9.

19. Tessa M, Kalliope K. Papadopoulou and Anne Osbourn. Metabolic and functional diversity of saponins, biosynthetic intermediates and semi-synthetic derivatives. Crit Rev Biochem Mol Biol. 2014; 49(6):439-62.

20. Al-Olwied AA. Comparative study of synthetic fertilizers and organic manures on some Mung Bean (Vigna radiata (L.) Wilczek) genotypes-1, effect on growth parameters and photosynthesis productivity. American-Eurasian J Agric Environ Sci. 2016; 16(4):666-76.

21. Pandey SK, Hema S. A simple, cost-effective method for leaf area estimation. J Bot. 2011.

22. Emongor VE. Effects of Moringa (Moringa oleifera) leaf extract on growth, yield and yield components of Snap Beans (Phaseolus vulgaris). BJAST. 2015; 6(2):114-22.

23. Geuns JMC. Steroid hormones and plant growth and development. Phytochemistry. 1978; 17:1-14.

24. Ohana P, Delmer DP, Carlson RW, Glushka J, Azadi P, Bacic $\mathrm{T}$, et al. Identification of a novel triterpenoid saponin from Pisum sativum as a specific inhibitor of the diguanylate cyclase of Acetobacter xylinum. Plant Cell Physiol. 1998; 39:144-52.

25. Patricia O, Deborah D, Gail V, Moshe B. Glycosylated Triterpenoid Saponin: A specific inhibitor of diguanylate cyclase from acetobacter xylinum. Biological Activity and Distribution. Plant Cell Physiol. 1998; 39(2):153-9.

26. Rahman A, Tsurumi S, Amakawa T, Soga K, Hoson T, Goto $\mathrm{N}$, et al. Involvement of ethylene and gibberellin signalings in chromosaponin l-induced cell division and cell elongation in the roots of Arabidopsis seedlings. Plant Cell Physiol. 2000; $41: 1-9$. 